\title{
Perspectives of surgery in the third millennium in all continents from an interdisciplinary point of view
}

\author{
Karel Novák · Marcel Hajek
}

Published online: 27 April 2016

(C) Springer-Verlag Wien 2016

\begin{abstract}
There are ten simple questions concerning the philosophy and future discussed in this editorial, in which reflects the main topic of the Jubilee World Congress of ICS, organized for the 80th anniversary of the founding of this oldest world surgical organization in Prague and in Pilsen in September 2015 (see Tab. 1).
\end{abstract}

Keywords Perspectives of surgery $\cdot$ 3rd millennium

\section{What is surgery?}

a) Cheir ergein - just manual skill?

b) Skill + science + art?

c) Skill + science + art + faith + fantasy + sorcery?

d) In a thousand years this field will be seen totally differently and the above mentioned definitions won't be valid.

2. Is it possible to foretell the future? - A comparison between Jules Verne and Theodor Billroth

Jules Verne (1828-1905) - Fig. 1a.

Why was he so successful?

In his work he combined his knowledge of history, contemporary science, faith in man, humane views

\footnotetext{
The supplement is dedicated to Jubilee World congress of International College of Surgeons 2015.

The publishing was sponsored by the Ministry of Health of the Czech Republic.
$\triangle$ Prof. K. Novák
karnova@tiscali.cz
1 Czech Section, ICS, Žižkova 748, 33701 Rokycany, Czech Republic

and political realism, and he lightened dramatic moments with goodhearted humour.

His heroes travelled in space, they had helicopters, airplanes, airships and other modern means of transport, they overcame natural disasters and social catastrophes, villains' and lunatics' attempts to control mankind and they were noted for their sophistication and humanism.

Theodor Billroth (1829-1894) - Fig. 1b.

"A surgeon who tries to suture a heart wound
deserves to lose the esteem of his colleagues"

Jules Verne's contemporary. A great surgical, cultural and social personality. He reached immense success and influenced his field of medicine. He fatally failed when he tried to foretell the heart operation. Why? He

Tab. 1 Ten basic questions of this article

\begin{tabular}{|c|c|}
\hline Question number & Question \\
\hline 1 & What is surgery? \\
\hline 2 & Is it possible to foretell its future? \\
\hline 3 & $\begin{array}{l}\text { Is surgery on the rise, is it stagnating or is it on the } \\
\text { decline? }\end{array}$ \\
\hline 4 & What does and will the future of surgery depend on? \\
\hline 5 & What will the future bring for surgeons? \\
\hline 6 & $\begin{array}{l}\text { Is it worth trying to change the future development of } \\
\text { surgery? }\end{array}$ \\
\hline 7 & $\begin{array}{l}\text { Where are the borders of surgical intervention into } \\
\text { human integrity? }\end{array}$ \\
\hline 8 & What will the social role of a surgeon be in the future? \\
\hline 9 & $\begin{array}{l}\text { Do surgical organizations contribute to the progress or } \\
\text { stagnation of surgery? }\end{array}$ \\
\hline 10 & $\begin{array}{l}\text { Why are these and related issues and questions impor- } \\
\text { tant? }\end{array}$ \\
\hline
\end{tabular}


Fig. 1 a Jules Verne (18281905), b Theodor Billroth (1829-1894)
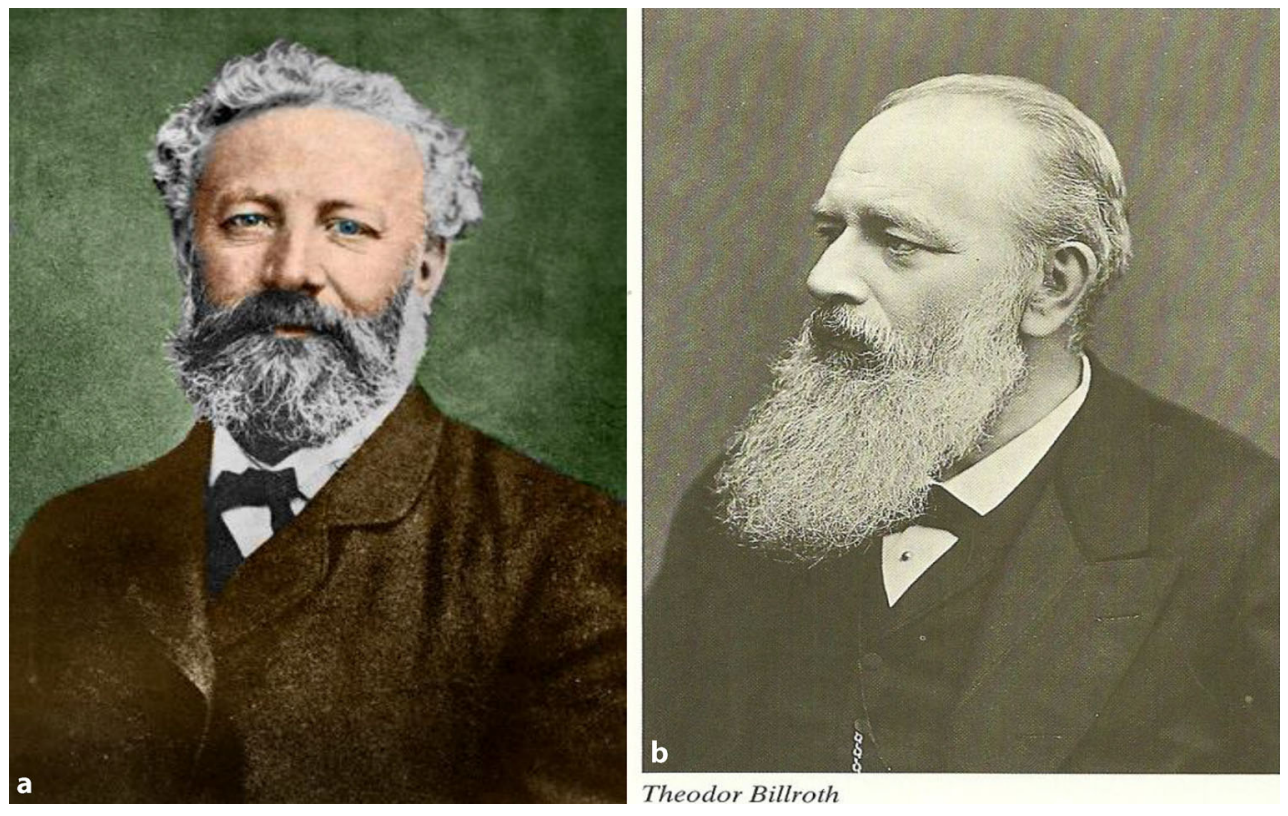

Theodor Billroth strictly relied on the contemporary science and had little imagination.

3. Is surgery on the rise?+ Is it stagnating? ${ }^{0}$ Or is it on the decline?-

+ Surgical techniques are constantly improving.

+ New operational procedures and approaches appear.

+ Better results are reached.

0 The optimal way of educating surgeons is not unified yet.

0 Most talented physicians are losing interest in surgery.

0 Specialization in surgery has its pros and cons.

- Non-surgical and alternative procedures extrude surgery even in situations where it is not effective.

- Financial demands on modern methods are not economically met.

4. What does and will the future of depend on?

- Natural changes and development of mankind

- Political development - peace or war

- Economic prosperity or failure

- State of the global population's health

- Epidemiology of surgical diseases

- Scientific discoveries in the development of man Operator and his physical and mental abilities. Will it change in only a thousand years?

- Legal environment and development of ethics

- Activity of surgical organizations and individual activities.

This list is not complete; it only demonstrates the complexity of the issue. Combinations are innumer- able. Surgeons have only part of the problem in their hands.

It is evident that we are not able to answer many of these questions and, above all, we are not able predict the consequences of their mutual multiple combination.

This is a reason that future generations will only know that we have been dealing with them and we have tried to look for ways leading to their solution.

5. Will the surgeon be a god among apostles or a slave stressed (whipped) by economists, lawyers, the patients' relatives, politicians, and businessmen?

Will the surgeon remain among the physicians or will he return to the level of a medieval craftsman despite managing the latest technologies (Fig. 2a, b)?

6.Is it worth trying to change the future development of surgery?

- Every animal species or every social group attempts to guarantee and improve the future for new generations.

- The future of mankind is insecure on all continents.

- Favorable development requires super-specialization of surgery.

- Unfavorable development, wars and catastrophes require provision of basic standards for extreme conditions.

- A thought arises to develop super-specialization on some continents and to fight for basic standards on others.

- However, it causes a clash between ethics and humanism on the one hand and economic possibilities of the continents and states on the other hand. 

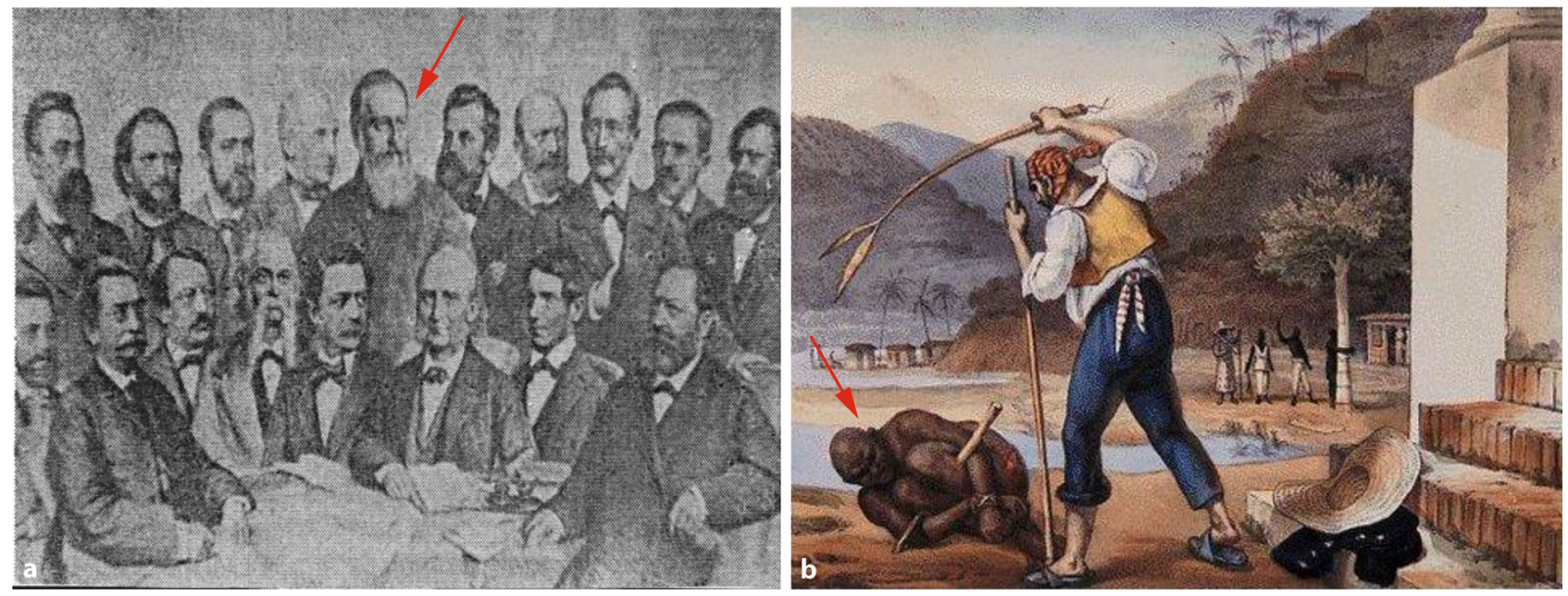

Fig. 2 These figures have a symbolic function. Theodor Billroth in a symbolizes a god among apostles, the slave in b symbolizes a stressed (whipped) surgeon in the future - see text

\section{Where are the borders of surgical intervention into human integrity?}

Both mini- and micro-invasiveness are common today. Transplantations of tissue, organs, and even total facial transplantation are a part of clinical surgery. Replacement of tissues and parts of organs by stem cells are the nearest reality. Hopefully we will be soon able to connect an interrupted spinal cord.

Shall we cooperate with genetic engineering and help it come true using micro-surgery?

Shall we change man physically and create supermen and superwomen?

Shall we implant anything into the brain and change the substance of unsound as well as sound human thinking and behavior?

Shall surgery prepare man for life in extreme conditions or outside the Earth?

Shall we try to ban such thoughts now or wait until an ambitious and lunatic colleague turns to them?

Shall we and other physicians be referees in these decisions or shall inscrutable politicians or priests decide?

What is fantasy and what is near reality?

Verne or Billroth (Fig. 1)?

\section{What will the social role of a surgeon be in the future?}

\section{Human society does not appreciate the huge economic contribution of surgery}

Large numbers of saved lives, restored health, return to active life, return to work, to the family, to reproduction. Surgery will continue to fulfil this role, but it is necessary to persuade society about this. The economically powerful know little about it and do not support surgery sufficiently. Philosophers and lawyers seem to be aloof. There are considerable dif- ferences between continents and countries. Surgery and medicine in general will always have to respond to the needs of the society, but they mustn't cross the borders of ethics and humanity and mustn't ignore the natural biological and historical development of man.

\section{Do surgical organizations contribute to progress or stagnation of surgery?}

All organizations, including International College of Surgeons (ICS), answer the question positively. But it does not always correspond with reality and truth. We are overwhelmed with innumerous scientific papers, whose results are shortly after denied.

There are no visionaries like Max Thorek or Jules Verne, and organizations pay little attention to completion of great issues, such as world or regional standards, preparation of teams for extreme conditions as well as economic support of these activities. There are too many policies and little cooperation on major scientific issues. Despite these drawbacks, organizations, including ICS, have a considerable working capacity, which is often fruitlessly disintegrated by local and continental interests and diverse policies inside the organizations.

Progress means to define basic issues and cooperate on them.

\section{Why are these and related issues and ques- tions important?}

Most surgeons are familiar with these questions.

Economic and other pressures force most surgeons to spend a disproportional amount of time in the operating theatre and prevent them from a broader perspective of their view and personality.

In this way, the leading medical and important social role of the field from the times of Billroth or Thorek has disappeared. 


\section{editorial}

It is necessary to give an opportunity in the operating theatre to the young, healthy and physically fit generation and to use the older, more experienced generation to solve the future of the field. Billroth and
Thorek attempted it in their 50s and 60s. Who will develop their ideas and visions in the third millennium?

Conflict of interest K. Novák and M. Hajek state that there are no conflicts of interest. 